Working Paper No. 590, 2003

Reconciling the Evidence on the Knowledge Capital Model

by Henrik Braconier, Pehr-Johan Norbäck and Dieter Urban

IUI, The Research Institute of Industrial Economics

P.O. Box 5501

SE-114 85 Stockholm

Sweden 


\title{
Reconciling the Evidence on the
}

\section{Knowledge Capital Model ${ }^{1}$}

\author{
Henrik Braconier \\ National Institute of Economic Research \\ Pehr-Johan Norbäck ${ }^{2}$ \\ The Research Institute of Industrial Organization \\ Dieter Urban \\ Johannes Gutenberg - University of Mainz
}

\begin{abstract}
The Knowledge Capital Model (KC-model), described in Markusen (2002), encompasses both market size (horizontal) as well as factor endowment (vertical) explanations to why multinational production occurs. Although the KC-model seems intuitively appealing, the empirical support has, so far, been weak and even confused. In this study, we find strong, robust and consistent support for the KC-model. In contrast to previous studies, our skill measures follow directly from the model. We also use an enlarged dataset, where the data coverage is significantly improved. Our results also give estimated surfaces remarkably similar to theoretical simulations of the $\mathrm{KC}$-model. In addition, the results give important insights into why previous studies have yielded such diverse results.
\end{abstract}

JEL classification: F12, F23

Keywords: Multinational Enterprise, Knowledge Capital Model, Vertical FDI

(January 31,2003 )

\footnotetext{
${ }^{1}$ Financial support through the EU-Commission Fifth Framework Program (Grant-No.: FMRX-CT-0215) is gratefully acknowledged. The paper was partly written when Dieter Urban was TMR-Fellow at London School of Economics.

${ }^{2}$ Pehr-Johan Norbäck, Research Institute of Industrial Economics, P.O. Box 5501, SE-114 85 Stockholm. Email: PJN@iui.se, durban@uni-mainz.de, henrik.braconier@konj.se
} 


\section{Introduction}

In this paper, we estimate the Knowledge Capital Model (KC-model) of Foreign Direct Investment (FDI), described in Markusen (2002). The model is a synthesis of models of horizontal FDI, where FDI is driven by the access to host-country markets, and models of vertical FDI, where relative labor-endowment differences are the sources of FDI. Earlier studies have found weak or mixed evidence on the KC-model, mostly stemming from the weak support for the vertical part of the model. Thus, they find little support for the notion that FDI may take place in order to benefit from factor endowment differences across countries. In contrast to previous empirical studies, we find firm and robust evidence in favor of the $\mathrm{KC}$-model and its vertical component.

We argue that our robust results follow from two crucial shortcomings in the previous empirical analysis. As the KC-model predicts that vertical FDI should primarily flow from small skilledlabor abundant countries to large unskilled-abundant ones, we obviously need to include data points of such combinations of home- and host countries, which was usually not done in previous studies. In this paper, we use an extensive dataset on affiliate sales, covering 56 home countries and 85 host countries, which means that we cover a far larger share of the endowment space than previous studies. In particular, we also have a better coverage of factor endowment combinations where vertical FDI should occur.

Apart from data coverage, we geometrically derive our empirical specification within the socalled Edgeworth endowment box diagram, whereas the empirical set-up in previous studies has been based on an indirect mapping from theory to estimation. This difference proves to be crucial in the area of the factor box, where the KC-model typically fails in empirical studies, i.e. when the home country is skilled-labor abundant and considerable vertical FDI is predicted. Thus, we conclude that previous empirical studies have found weak evidence for the KC-model due to the fact that the data coverage has been poor and the mapping from theory to empirics indirect. Our 
empirical results are also easy to visualize, and these plots do not only show a remarkable resemblance to the theoretical predictions but also give further insights into why previous studies yielded such diverse results.

The paper is organized as follows. In section 2, we review theory and evidence; section 3 describes the estimation equation and the data, while section 4 presents the estimation results. Section 5 reconciles our results with earlier literature. Section 6 concludes.

\section{Theory and Evidence on the KC-model}

MNEs are often classified to be of the horizontal or vertical type, according to their type of affiliate operations. In general, horizontal MNEs conduct FDI in order to improve the access to host country markets, while vertical FDI is undertaken to reap benefits from international factor price differences. In the Knowledge Capital Model (KC-model), developed in Markusen (1997) and Markusen (2002), FDI is driven by both factor costs and market access and, thus, it incorporates both vertical and horizontal FDI. In this section, we will briefly outline the model and refer to Markusen (2002) for a detailed description.

In the KC-model, there are two countries, home (i) and foreign (j); two factors of production, skilled (S) and unskilled (U) labor; and two goods, $\mathrm{X}$ and Y. Y-production is perfectly competitive and subject to constant returns to scale. FDI can only occur in the X-sector. Good X is produced with increasing returns to scale, using a three-stage production process. In the first stage, a firm must undertake some headquarter services such as R\&D, management, accounting or marketing activities, which generate firm-level fixed costs. In the second stage, plant-level fixed costs are incurred. In the final stage, production takes place and X-firms compete in a Cournot fashion. Markets are assumed to be segmented and trade costs exist when shipping Xgoods across borders. 
Assuming a ranking where headquarter activities are more skilled-labor intensive relative to (integrated plant and final) production of $\mathrm{X}$ which, in turn, is more skill-intensive than $\mathrm{Y}$ production, three firm types can emerge:

- Horizontal MNEs have their headquarter activities tied to the home plant and duplicate the domestic production plant in the host country. MNEs of the horizontal type sell their entire production locally.

- Vertical MNEs slice up the value chain by locating high-skilled labor intensive headquarter services in the high-skilled labor abundant home country, and relatively lowskilled labor intensive production activity in the low-skilled labor abundant host country. MNEs of the vertical type export (part of) their production to the home country.

- National firms solely produce in the home country and serve foreign markets by exports.

Figure 1 shows simulated levels of affiliate sales of country $i$ firms in country $j$, taken from Markusen (2002). ${ }^{3}$ Country endowments of skilled and unskilled labor are measured on the vertical and the horizontal axis, respectively, where $s_{i}$ is the home country's share of the world endowment of skilled labor, whereas $u_{i}$ is its share of the world endowment of unskilled labor. The origin of the home country is in the S-W corner, while the origin of the potential host country is in the N-E corner of the diagram. Above the diagonal, the home country is skill abundant relative to the host country. Finally, the relative economic size of the home country grows along the diagonal from S-W to N-E.

Vertical MNEs appear N-W of the diagonal line, where relative endowments are very different. Differences in factor prices induce a fragmentation of activities, with headquarters locating in the skilled-labor abundant country and production in the unskilled-labor abundant country. However, the incentive for such vertical fragmentation is strongest when the home country is

\footnotetext{
${ }^{3}$ We thank James Markusen for providing us with simulation results.
} 
simultaneously skilled-labor abundant and small (generating the peak in affiliate sales around point $\mathrm{V}$ in Figure 1). In a large home country, firms have weaker incentives to serve the home market from a branch-plant in the host country due to trade costs.

Horizontal MNEs are concentrated close to the center of the Edgeworth box (generating peaking affiliate sales at point $\mathrm{H}$ ), where relative endowments and relative country size are rather similar. Intuitively, dissimilar size penalizes horizontal MNEs as the smaller market still requires fixed investment costs. In that case, national firms in the larger market are predominant. Horizontal MNEs emerge when the home country is slightly more high-skilled labor abundant, because the $\mathrm{X}$-sector itself is high-skilled labor intensive, relative to the Y-sector. However, when countries become too dissimilar in endowments, diverging factor prices can be exploited by fragmentation.

The empirical evidence on the KC-model is mixed. Table 1 gives an overview of previous empirical results. Pooling US inward and outward FDI data, Carr et al. (2001), henceforth CMM, provide strong support for the $\mathrm{KC}$ model, finding that affiliate sales (i) increase in the total income of the host and home countries, (ii) increase in skill differences, while (iii) dissimilarities in size reduce affiliate sales. In addition, they find that (iv) home countries which are simultaneously skilled-labor abundant and small, have higher affiliate sales. These findings are broadly consistent with the pattern of FDI in Figure 1.

However, Markusen and Maskus (2001) find a negative relation between affiliate sales and skilled labor abundance in the home country when investigating outward US FDI only. Moreover, Markusen and Maskus (2002a) formally reject the KC-model in favor of a Horizontal model, where vertical FDI is ruled out by assumption. Blonigen, Davies and Head (2002), henceforth $\mathrm{BDH}$, find further evidence for the Horizontal model. Regressing affiliate sales from the CMM sample, as well as FDI stocks, on absolute values of differences in skill endowments and size, they find that such differences - whether positive or negative - decrease affiliate sales. 
Recently, a few papers have also provided some evidence in favor of vertical FDI in the KCmodel, however. Davies (2002) argues that the estimation equation of CMM must be amended by including additional terms in CMM's original specification. Based on Figure 1, he argues for a third-order polynomial in skill differences to detect the maximum point (where horizontal FDI peaks) and the inflection point (where horizontal MNEs are being replaced by vertical MNEs). However, favorable evidence for an inflection point is only found when using FDI stocks proxying for FDI and total years of schooling proxying for skills, rather than the ILO data on skills and data on affiliate sales used by CMM.

Braconier, Urban and Norbäck (2002) investigate the link between wage costs and FDI using outward FDI data for Sweden and the US. An advantage of their paper is that pooling these data greatly enhances the coverage of bilateral country pairs in the endowment box. They find strong evidence of the KC-model, confirming the results in CMM (2001). However, their skill-measure is derived from wage data (using the home to host difference in relative wages between skilled and unskilled labor), rather than from the actual endowments of skilled and unskilled labor, from which the $\mathrm{KC}$ model is defined. ${ }^{4}$

Summing up the literature has produced surprisingly mixed results. In the following sections, we investigate the sources of this heterogeneity of the evidence on the KC-model.

\section{Contributions}

This paper makes three specific contributions. First, our empirical specification follows directly from theory, especially in the case of relative skill endowments. Second, we also use a new data set on affiliate sales, which has a superior coverage of home and host countries as compared to previous studies. Finally, our results can be directly compared to the theoretical predictions of the KC-model illustrated in Figure 1. 


\subsection{Re-defining the Estimation Equation}

There are several possible mappings of the KC-model to data. ${ }^{5}$ Previous empirical specifications in general, and the CMM specification in particular, only constitute an indirect mapping of the theoretical predictions of Figure 1, as can be seen in Table 2. Note that the main independent variables of the KC-model are the home country share in world endowments of high-skilled and low-skilled labor, $s_{i}$ and $u_{i}$. Instead, using ILO data skilled labor, the corresponding variables used in the CMM empirical specification are home and host country GDP and the home and host country difference in the share of skilled labor in the total population of the respective home and host countries, SKILLDIF. Furthermore, CMM capture movements along the SW-NE diagonal of Figure 1 only through the squared-difference of GDP between the home and the host country, GDPDIFSQ. This implies that a U-shape or an inverse U-shape is imposed on the data.

We propose an alternative functional form that can be directly mapped from theory. This specification is also defined in Table 2, where a comparison to CMM is also made. Note that coordinates in the Edgeworth box of Figure 1 give the position of bilateral pairs of countries. Hence, the law of Pythagoras implies that the size of a country can be calculated by the length of a ray from the origin to its endowment point in the Edgeworth box, i.e $S I Z E_{i}=\sqrt{u_{i}^{2}+s_{i}^{2}}$. To account for the fact that size may have a nonlinear effect on MNE activities and affiliate sales, we also include its square, SIZESQ $Q_{i}$. Together, these two variables will capture how movements along rays from the home country origin affect the level of MNE activities, measured as affiliate sales. Skill abundance is then measured directly as the slope of a ray, from the origin to a point in the box. i.e $S K I L L_{i}=\frac{s_{i}}{u_{i}}$. Note that the variables $S I Z E_{i}$ and $S K I L L_{i}$ completely define the home country's position in the Edgeworth box.

\footnotetext{
${ }^{4}$ Other studies on vertical FDI that do not involve structural estimation of the KC-model, are Hummels, Rapoport and Yi (1998), Hummels, Ishii and Yi (2001).

${ }^{5}$ A similar evaluation stems from Markusen and Maskus (2002b): “... the knowledge-capital model, a hybrid of a vertical and a horizontal model, is a conceptually difficult one for estimation. Relationships predicted by the model are not only non-linear but non-monotonic. The implication of this is that there is room for reasonable disagreement as to what the appropriate estimation equation should be." (p. 1)
} 
In line with theory, we also employ the same non-linear interaction term as CMM and define $I N T E R_{i}$ as the product of $S I Z E_{i}$ and $S K I L L_{i}$. We also control for the actual size of the Edgeworth box in the same way as CMM, by including the total income of the two countries, SUMGDP. This gravity effect should have a positive impact on affiliate sales. The additional control variables are the same as those used by CMM. Consequently, we propose the following estimation equation:

$$
\begin{aligned}
& \text { RSALES }=\alpha_{1}+\alpha_{2} S U M G D P+\alpha_{3} S_{I Z E_{i}}+\alpha_{4} S_{S Z E S Q_{i}}+\alpha_{5} S_{K I L L}+\alpha_{6} I_{\text {INTER }} \\
& +\alpha_{7} \text { PROT }_{i}+\alpha_{8} \text { PROT }_{j}+\alpha_{9}{I N V C_{j}}_{j}+\alpha_{10} I_{N T E R P R O T}+\alpha_{11} D I S T+\varepsilon
\end{aligned}
$$

where RSALES is the real total sales of country $i$ 's affiliates in country $j$. Regarding the additional control variables of CMM, $P R O T_{j}$ denotes an index of trade barriers to country $j$. Increasing protection should increase the tariff-jumping incentive for horizontal FDI in host country $j$ and, hence, increase affiliate sales. $P R O T_{i}$ denotes the same index of trade barriers but applied to country $i$. Increasing protection in the home country makes re-exporting to the home country more costly and should therefore reduce affiliate sales. $I N V C_{j}$ denotes an index of the costs of investing in country $j$. Increasing investment protection should therefore reduce affiliate sales. The three latter variables are collected by World Economic Forum and are further described in the data appendix. INTERPROT ${ }_{j}$ is an interaction variable between the level of protection in country $j, P R O T_{j}$, and the square of the skill-difference, SKILLDIF. CMM are agnostic about the sign of this variable, but weakly suggest a negative impact. ${ }^{6}$ Finally, we also include geographical distance, DIST, between the home and the host country capitals. Definitions of independent variables, their expected influence on affiliate sales and a comparison to CMM are given in Table 2.

\footnotetext{
${ }^{6}$ Host country trade costs affect only horizontal MNEs. Moreover, horizontal MNEs appear when countries are similar in endowments. CMM therefore suggest that INTERPROT $T_{j}$ has a negative impact. However, simulations show a much more complicated interaction, and CMM conclude that this is not a "theoretically sharp hypothesis".
} 


\subsection{Collecting new Data}

The second improvement on the previous literature is to increase the coverage of FDI data. We have collected data from the OECD Globalization Database and supplement these with national data on inward and outward FDI from the US, Germany and Italy, combined with outward FDI data from Sweden and Japan. ${ }^{7}$ To keep the database homogeneous, we selected data for the years 1986, 1990, 1994 and 1998. We have bilateral affiliate sales data for 56 home countries and 85 host countries with at least one observation. The coverage of country pairs increases about six times as compared to US inward and outward FDI data alone. As we have taken data from different sources, there are differences in definitions of FDI, coverage, and data quality across observations. The OECD Globalization Database and some national sources sometimes also report zero values of affiliate sales. Those have been kept. For other sources, missing values may either be unknown or undisclosed and hence, we cannot set the affiliate sales of country pairs missing in the official statistics to zero, even though it may be appropriate in many cases. Affiliate sales data are in constant 1990 billion US Dollar. Summary statistics can be found in Table A1.

To see the improvements in the coverage of our affiliate sales data, Figure 2 shows the coverage of the commonly used US inward and outward data on affiliate sales ${ }^{8}$ in an Edgeworth box diagram similar to Figure 1. Using the previously mentioned ILO data on skilled labor, we depict the home country skilled-labor share of the combined home and host country skilled-labor endowment on the vertical axis, $s_{i}$, and the home country unskilled-labor share of the combined home and host country unskilled labor endowment on the horizontal axis, $u_{i}$.

We see that US outward FDI observations are only found in the upper right-hand corner and US inward FDI observations in the lower left-hand corner. This distribution reflects the fact that the

\footnotetext{
${ }^{7}$ A precise data description is found in the Appendix

${ }^{8}$ See Carr et al. (2001) and Markusen and Maskus (1999, 2001).
} 
US economy is the largest in this dataset. Then, we make a comparison with our new dataset and in Figure 3, we see that the coverage of the Edgeworth box has increased substantially.

For comparison, we follow Blonigen et al. (2001) and Davis (2002) and also collect FDI stock data under the assumption that total bilateral FDI stocks are closely correlated with affiliate sales. These data are obtained from OECD and cover 57 host countries and 58 home countries. The coverage of host countries is hence lower in the stock data. Moreover, the correlation between FDI stocks and affiliate sales is 0.79 . Thus, the results based on FDI stocks must be interpreted with care. 461 observations of FDI stocks are available from two data sources - the inward FDI data source of the host country and the outward FDI data source of the home country, and the correlation between the two datasets for the same observations is $0.91 .^{9}$

\section{Results}

First, we present our baseline specification and then we undertake a number of robustness checks.

\subsection{Re-estimating the KC-model}

In column (i) of Table 3, we present the estimates for our specification in (1), using affiliate sales as the dependent variable. The coefficients for the variables of interests are significant at the one per cent level with the expected signs. In particular, there are more affiliate sales if the home and the host country have a similar relative size (coefficient on $S I Z E_{i}$ positive and on $S I Z E S Q_{i}$ negative) and affiliate sales increase in the high-skilled labor abundancy of the home country, relative to the host country (coefficient on $S K I L L_{i}$ positive). Our results are in line with the prediction of the KC-model that small and high-skilled labor abundant home countries have proportionately most affiliate sales in host countries (negative coefficient on $I N T E R_{i}$ ).

Turning to the control variables, the overall size of the home and the host country (SUMGDP), investment costs and home country protection have the expected signs, albeit home country

\footnotetext{
${ }^{9}$ There are similar problems with affiliate sales data. This is described further in the Appendix.
} 
protection is not significant. Distance is highly significant, but not the interaction term of squared relative skill endowment and protection of the host country $\left(I N T E R P R O T_{j}\right)$. Only in the case of host country protection do the results contradict the KC-model. ${ }^{10}$ In column (ii), we add home and host country fixed effects and the results in favor of the KC-model are even stronger. While all terms with variables of interest remain highly significant with the expected signs, the host protection now also becomes significant with correct sign.

Blonigen et al. (2002) dispute the results in CMM (2001), because a structural break occurs when the sample is split into home country skilled-labor abundant and unskilled-labor abundant observations. We find no such breaks in our estimations, as follows from columns (iii) and (iv). The results from the FDI stock data are also encouraging. In both specifications without home and host country fixed effects (v) and with home and host country fixed effects (vi), we find all terms with variables of interest $\left(S K I L L_{i}\right.$ and $\left.S I Z E_{i}\right)$ to be significant at the one per cent level with the expected sign.

\subsection{Robustness}

To test the robustness of our specification, we first include additional control variables in the specification in (1), and later also apply alternative econometric techniques. Column (i) in Table 4 replicates column (ii) in Table 3 with an additional neighbor dummy, indicating whether countries $i$ and $j$ have a common border (ADJACENT).

From column (i), we see that no qualitative changes in estimates occur, while the border dummy variable is highly significant. Column (ii) shows results for a tobit regression, as we have roughly 200 observations with a zero value of affiliate sales. Once more, no qualitative change of coefficients occurs.

\footnotetext{
${ }^{10}$ Similar problems are encountered in Carr et al. (2001). Braconier, Norbäck and Urban (2002) point out a
} 
A potential problem is heteroscedasticity, which remains even though we control for the total size of the home and host country and use the White correction. In column (iii), we therefore apply a WLS regression, where we use the product of home and host country GDP as the weight. As expected, this WLS estimation leads to a substantial increase in $\mathrm{R}^{2}$. However, there is no substantial change in estimated coefficients compared to the baseline specification. We also observe similar results when using the sum of home and host country GDP as weights (column iv).

\subsection{Discriminating between alternative models}

A significant advantage of our approach is that we can reproduce a direct graphical image of our estimates of (1) in an Edgeworth-box diagram. This is shown in Figure 4, which depicts the implied surface from column (ii) in Table 3. There is a striking similarity between the theory in terms of the surface in Figure 1 and the estimated surface in Figure 4, which exhibits an inverse U-shape in affiliate sales along the diagonal connecting the country origins, stemming from extensive horizontal FDI, when countries are similar in size. Moreover, the maximum affiliate sales are predicted when the home country is small and skilled-labor abundant at the same time, which corresponds to large amounts of vertical FDI. Hence, our specification (1) gives strong evidence for the KC-model.

The estimated surface in Figure 4 also provides an alternative way of gauging the $\mathrm{KC}$-model against competing models. Markusen and Maskus (2002a) nest a Horizontal model (which, by assumption, rules out vertical MNEs) and a Vertical model (which, by assumption, rules out horizontal MNEs) within an unrestricted KC model. Figures 5 and 6 show the surfaces implied by the Horizontal and the Vertical model, respectively. First, note that our estimated surface (Figure 4), revealing a maximum of affiliate sales at point $V$, is clearly not consistent with the Horizontal model (Figure 5). While the KC-model and the Horizontal model give rise to quite distinct

multicolliniarity problem between the trade- and investment costs measures. 
surfaces, the surface of the Vertical model is more similar to that of the $\mathrm{KC}$ model. However, a major difference is that the inverse U-shape along SW-NE diagonals in the $\mathrm{KC}$-model (Figure 1) is almost absent in the Vertical model (Figure 6). Hence, identifying the local maximum point $\mathrm{H}$ in the middle of our estimated surface (Figure 4) is not consistent with the Vertical model. In contrast, the simultaneous concentration of sales at points $\mathrm{H}$ and $\mathrm{V}$ in our estimated surface is only consistent with the $\mathrm{KC}$ - model.

This visual inspection is also suggestive of more formal testing. The Horizontal model (Figure 5) shows that affiliate sales should follow an inverse U-shape both when the home country increases in size and in skill abundance. To allow for the latter, the square of the variable $S K I L L_{i}$, labeled SKILLSQ $Q_{i}$ is added to (1). Both the KC-model and the Horizontal model should produce a positive sign on $S I Z E_{i}$ and a negative sign on $S I Z E S Q_{i}$. However, as noted above, these effects should be small in the Vertical model (Figure 6). All three models predict a positive sign on $S K I L L_{i}$, whereas the effect on $S K I L L S Q_{i}$ should be negative in the Horizontal model while this effect is less clear-cut in the Vertical and the KC-model. This will be discussed in more detail in section 5.2.

A negative coefficient on INTER $R_{i}$ implies that affiliate sales are larger for small and skilled-labor abundant countries. Comparing Figures 1, 5 and 6, a negative coefficient on $I N T E R_{i}$ would therefore reject the Horizontal model in favor of the KC-model and the Vertical model. According to Markusen and Maskus (2002a), affiliate sales in the Vertical FDI model depend positively on the interaction of skill difference and the sum of home and host country GDP (defined as INTSUM $\left.=S K I L L S Q_{i}{ }^{*} S U M G D P\right)$ in contrast to the Horizontal FDI and the KC-models. They also argue that the effect of $S U M G D P$ is (close to) zero in the Vertical model, while this gravity effect should increase affiliate sales both in the Vertical and the Horizontal model. Finally, we add as controls the remaining variables in (1), including the neighbor variable. To facilitate a comparison with previous papers (summarized in Table 1), we use the OLS-specification without fixed effects. 
The results in Table 5 show that we can reject the Horizontal and the Vertical models in favor of the $\mathrm{KC}$-model, as the coefficients on the size variables are inconsistent with the vertical FDI model while $I N T E R_{i}$ is inconsistent with the Horizontal model. Hence, only the $\mathrm{KC}$-model is consistent with all coefficients of variable interest. ${ }^{11}$ Thus, we can also formally reject the Horizontal and Vertical models in favor of the KC model.

\section{Reconciling the evidence}

So far, we have found strong support for the $\mathrm{KC}$ model, which stands in sharp contrast to the earlier mixed results in the literature. However, in this final section, we argue that given our estimation approach, there is a surprising consistency with the previous literature to be recovered.

\subsection{The role of sample coverage}

In section 2, we noted the results in CMM (2001) being supportive of the KC-model whereas a number of papers, such as Markusen and Maskus (2001) and Blonigen, Davies and Head (2002), questioned these results. The latter papers uncover that US outward FDI is skilled-labor seeking, whereas the opposite holds for US inward FDI. BDH (2002) argue this evidence to be in favor of the Horizontal model, rejecting the $\mathrm{KC}$-model. However, looking at the estimated surface in Figure 4, these results are consistent with the KC-model. As revealed by Figure 2, the US is so large that observations on US inward FDI are located far down to the S-E (below the 45 degree line), whereas US outward FDI is located far up to the N-W (above the 45 degree line). Comparing with the estimated curvature in Figure 4, US outward FDI may well decrease when the US becomes more skill abundant, whereas the opposite holds for inward FDI. In fact, it seems that it is precisely by pooling these "local" curvatures that CMM (2001) are able to find support for the KC-model, despite the poor coverage of the US data in the center of the Edgeworth box.

\footnotetext{
${ }^{11}$ F-tests on the joint restrictions are available upon request.
} 
Figures 1 and 2 also illustrate why formal tests attempting to discriminate between the $\mathrm{KC}$-model and the Horizontal model, using the US data, have little power: there are virtually no observations capturing the vertical part of the KC-model in the US data. ${ }^{12}$ BDH (2002) attempt to circumvent this by using FDI stocks, which extensively increase the coverage as compared to the US sales data. Using FDI stocks, they cannot reject the Horizontal model in favor of the KC-model. However, stock data is a rather imperfect proxy for affiliate sales. We therefore re-estimated CMM (2001) on our extended data set on affiliate sales. For comparison, we also included estimates on FDI stock data from the OECD. The results are shown in Table 6.

In specifications (i) and (ii), we re-estimate the CMM-functional form without and with fixed effects (applied to home- and host country). Following BDH, we split the sample according to skillabundance in specifications (iii) and (iv), while FDI stock data are examined in specifications (v) and (vi). Even when using our affiliate sales data, which have an extensive coverage, compared to the US data, there is no consistent evidence on the KC-model. Only in specification (v), applying OLS to FDI stocks, do we find that the more high-skilled labor abundant is the home country relative to the host country, the larger are affiliate sales. In all other specifications, the skill variable SKILLDIF is not significant and often appears with the incorrect sign.

\subsection{The role of the empirical specification}

Given the weak support we find for the CMM specification, it is puzzling that our specification (1) provides such strong support for the KC-model (in terms of estimated coefficients, formal testing or graphics, applying both affiliate sales and FDI stock data). However, in section 3.1, we noted that the CMM specification is an indirect mapping from theory, while we measure the skill-abundance directly from the Edgeworth-box. This implies that the CMM skill-measure will not consistently measure the "true" skill abundance of the home country. ${ }^{13}$ This "distortion" becomes large when

\footnotetext{
${ }^{12}$ This is also suggested by Markusen and Maskus (2002b).

${ }^{13}$ This problem is magnified by the fact that there is no direct size measure of the home country (only differences in size appear in regressions), which means that the CMM specification provides a distorted measure for the home country's position in the Edgeworth box.
} 
the home country is skilled-labor abundant, as can be illustrated in Figure 7 where we plot the difference between our skill measure and CMM's, SKILL $L_{i}-$ SKILLDIF, for observations where the home country is skilled labor abundant. ${ }^{14}$ Note that this difference is equal to unity at the 45 degree line, but increasing and reaching a maximum in the area where vertical FDI is predicted by the KCmodel. Indeed, it is the variation in skill abundance in these observations which is instrumental for identifying the vertical part of the $\mathrm{KC}$ model and, hence, for rejecting the Horizontal model in favor of the $\mathrm{KC}$ model

From the estimated surface in Figure 6, our data also suggest that there is a single, smoothly shaped peak in affiliate sales when the home country is small and skilled-labor abundant. Indeed, it is through this finding that we identify vertical FDI. However, as noted in section 2, Davies (2002) argues for an alternative test for the vertical part in the $\mathrm{KC}$-model by searching for an inflection point where skill abundance increases when moving from S-E to N-W in Figure 1. Following Davies, we therefore estimated a specification of (1) using a polynomial of degree three in the skill variable, $S K I L L_{i}$.

Similar to his results on the ILO data (see Table 1), we find no evidence of an inflection point, and the estimated surface in Figure 8 is almost indistinguishable from that in Figure $4 .{ }^{15}$ However, this does not constitute evidence against the $\mathrm{KC}$ model; comparing our data in Figure 3 with the estimated surface in Figure 4, reveals that there are virtually no observations in the N-W region where inflection points should appear. Hence, our predicted surface in this area mirrors an out of

${ }^{14}$ Note that the difference between SKILL and SKILLDIF can be written:

$$
\Delta\left(s_{i}, s_{j}, S, U\right)=\frac{s_{i}}{u_{i}}-\left[\frac{S_{i}}{S_{i}+U_{i}}-\frac{S_{j}}{S_{j}+U_{j}}\right]=\frac{s_{i}}{u_{i}}-\frac{s_{i}}{s_{i}+\frac{U}{S} u_{i}}+\frac{1-s_{i}}{1-s_{i}+\frac{U}{S}\left(1-u_{i}\right)}
$$

where $S$ and $U$ are the total world endowment of skilled and unskilled labor. Note that $\Delta(1,0, S, U)=\infty$, $\Delta(0,1, S, U)=1$ and $\Delta\left(s_{i}, u_{i}, S, U\right)=1$ for $s_{i}=u_{i}$ and $S=U$.

${ }^{15}$ The estimates are available on request. 
sample prediction. ${ }^{16}$ In contrast, our estimated surface is generated from the area where there are observations: In this wide region in Figure 3, the $\mathrm{KC}$-model is unambiguously identified through the inverse U-shape along the S-W to N-E diagonal, and the peak of affiliate sales when the home country is small and unskilled labor abundant.

\section{Conclusions}

In this study, we estimate the Knowledge Capital Model described in Markusen (2002). We make three specific improvements on previous attempts to estimate this model. First, we geometrically derive measures of relative size and relative skill-endowments from the Edgeworth-box, which proves to be crucial for our results. Second, our estimation equation allows us to graphically compare our results to theoretical predictions based on simulations. Finally, we make a major effort in compiling data on affiliate sales for a large number of countries with diverse endowments. Hence, we have a far larger coverage of the factor-endowment box as compared to previous studies.

Previous studies have found mixed evidence on the KC-model, especially on its vertical FDI part. This follows partly from the fact that they use a much more limited set of data, which does not provide observations where vertical FDI is most likely to occur, i.e. when the home country is small and skill-abundant. Another reason why previous studies only provide weak empirical evidence on the $\mathrm{KC}$-model is that the common approach, based on $\mathrm{CMM}$, provides a measure of skill which becomes increasingly biased as the home country's skill-intensity increases.

In contrast, our empirical results give strong support for the KC-model, when we use our suggested empirical specification. The graphical image of our empirical results shows a remarkable similarity to simulations of the KC-model. The results are also very robust to changes in the specification. Consequently, we conclude that the KC-model seems to fit the data surprisingly well.

\footnotetext{
${ }^{16}$ Likewise, the estimated surface also shows positive sales in the region where the home country is highly unskilled-labor abundant.
} 


\section{References}

Barro, Robert E., and Jong-Wha Lee, (1996), International Measures of Schooling Years and Schooling Quality, American Economic Review, Papers and Proceedings, Vol. 86, pp. 218-223.

Blonigen, Bruce A., Ronald B. Davis, and Keith Head, (2002), Estimating the Kowledge-Capital Model of the Multinational Enterprise: Comment, NBER Working Paper No. 8929.

Braconier, Henrik, Pehr-Johan Norbaek, and Dieter Urban, (2002), Vertical FDI Revisited, Working Paper No. 579, The Research Institute of Industrial Organization (IUI).

Carr, David L., James R. Markusen, and Keith E. Maskus, (2001), Estimating the KnowledgeCapital Model of the Multinational Enterprise, American Economic Review, Vol. 91, No. 3, pp. 693-708.

Davies, Ronald B., (2002), Hunting High and Low for Vertical FDI, August, University of Oregon, mimeo.

Hummels, David, Jun Ishii, and Kei-Mu Yi, 2001, The Nature and Growth of Vertical Specialization in World Trade, Journal of International Economics, Vol. 54, pp. 75-96.

Hummels, David, Dana Rapoport, and Kei-Mu Yi, 1998, Vertical Specialization and the Changing Nature of World Trade, Federal Reserve Bank of New York Economic Policy Review, June, pp. 79-99.

Markusen, James R., and Keith E. Maskus, (2001), Multinational firms: Reconciling Theory and Evidence, in: Magnus Blomstrom and Linda S. Goldberg, ed., Topics in Empirical International Economics: A Festschrift in Honor of Robert E. Lipsey. Chicago, IL: University of Chicago Press for National Bureau of Economic Research.

Markusen, James R., and Keith E. Maskus, (2002a), Discriminating Among Alternative Theories of the Multinational Enterprise, Review of International Economics, 10(4), 694-707.

Markusen, James R., and Keith E. Maskus, (2002b), Estimating the Knowledge-Capital Model of the Multinational Enterprise: Reply, University of Colorado at Boulder, mimeo.

Markusen, James R., (1997), Trade Versus Investment Liberalization, NBER Working Paper No. 6231 .

Markusen, James R. (2002), Multinational Firms and the Theory of International Trade, Cambridge: MIT Press. 


\section{Appendix:}

\section{A. Data-description}

\section{Outward FDI}

We use the following outward FDI datasets:

Italian Outward FDI: turnover from REPRINT database, Polytecnico Milano

Swedish Outward FDI: total affiliate sales from IUI;

Japanese Outward FDI: total affiliate sales from Ministry of Economy, Trade and Industry, Wagakuni Kigyo no Kaigai Jigyo Katsudo, various issues. Without financial firms. The year 1988 of sales data are matched with control variables from 1986.

German Outward FDI, total affiliate sales from Deutsche Bundesbank, Kapitalverflechtungen mit dem Ausland, various issues. Without financial firms. Reporting of MNEs is voluntary.

For US outward FDI, total affiliate sales from BEA. The years 1986, 1990, 1994 are obtained from Carr, Markusen and Maskus (2001), the year 1998 is constructed from BEA (http://www.bea.gov).

\section{Inward FDI}

We also use the following Inward FDI datasets from OECD, Globalisation Database, CD-ROM, which, in turn, rely on national sources described there. Data were updated from the new hard-cover version OECD (2001) Measuring Globalisation - The role of multinationals in OECD economies - Volume I: Manufacturing Sector.

For UK inward FDI gross output is taken; the year 1989 is matched with control variables for 1990, the year 1996 is matched with control variables for 1998. There are no data for the year 1986.

For Turkish inward FDI the gross output is taken. The year 1991 is matched with control variables for 1990, the year 1996 with control variables for the year 1998. There are no data for 1986. Data are supplemented from OECD (2001) for 1998. (Production value)

For Irish inward FDI gross output is taken. The control variables for 1998 are matched with affiliate data from 1996.

Canadian Inward FDI: for the year 1986 turnover, for other observations gross output. Affiliate data from 1996 are matched with control variables of the year 1998.

French inward FDI: data from January 1, 1989 are matched with control variables for the year 1986. Data for January 1, 1999 are obtained from Feuvrier and Lehoucq (2000). L'implantation étrangère dans l'industrie française, SESSI. Data on affiliate turnover are used. Data from 1994 and 1998 are from OECD (2001). Turnover data of manufacturing sector are reported.

Mexican inward FDI: Turnover, data for the year 1985 are matched with control variables for 1986, data from 1993 are matched with the control variable year 1994, there are no data for 1998.

Inward FDI of Finland: the turnover of foreign affiliates in the year 1995 is matched with control variables for the year 1994, data of 1997 with 1998. The year 1998 is taken from OECD (2001).

Swedish inward FDI: Turnover of the year 1996 is matched with control variables for the year 1998. No data are available for 1986. New data on turnover for 1998 from OECD (2001).

Norwegian inward FDI: Gross output of the year 1991 is matched with control variables for 1990 and 1996 is matched with 1998. No data are available for 1986. New data on affiliate production for 1998 from OECD (2001).

Dutch inward FDI: Affiliate turnover data of 1995 are matched with data from 1994, affiliate data from 1996 are matched with 1998. No other years are available. Data for 1995 and 1998 are taken from OECD (2001).

Polish Inward FDI: from OECD (2001), turnover of foreign affiliates, The affiliate data for the year 1997 are matched with control variables for 1994 and affiliate data for 1999 with control variables for 1998.

Japanese inward FDI: Turnover of foreign affiliates, data for the year 1996 are matched with control variables for 1998. the year 1986 is not available.

German Inward FDI: Sales data based on voluntary reporting, and comprising all sectors are taken from Bundesbank, Kapitalverflechtungen mit dem Ausland, various issues. Double counting if a company has owners from several foreign countries; Dependent holding companies are excluded. For further information, see Bundesbank (2001) Kapitalverflechtungen mit dem Ausland, Sonderveröffentlichungen. The year 1986 is missing.

US inward FDI: from OECD (1999). The year 1998 is taken from OECD (2001). Turnover data.

Italian Inward FDI: from Reprint database of Politecnico di Milano, various years. (Cominotti, R., S. Mariotti, M. Mutinelli, Italia Multinazionale 1998, CNEL, Roma 1999; Cominotti, R., S. Mariotti, Italia Multinazionale 1994, CNEL, 1994; Cominotti, R., S. Mariotti, Italia Multinazionale 1992, CNEL, 1992; Onida, F., and G. Viesti (eds.), The Italian Multinationals, Croom Helm, New York, 1988). The year 1987 is used instead of 1986, 1993 instead of 1994, 1997 instead of 1998. Data refer to sales. Remark: this is the extended version covering more countries of the data reported in $\operatorname{OECD}(1999,2001)$.

All sales/production/turnover data are in Mill. USD, using exchange rates from OECD Economic Outlook (for Italy and Turkey WDI=period averages) and deflated by the US wholesale price index (from OECD, Economic Outlook). 
Whenever in- and outward data supplied the same home-host country-pairing, the outward FDI data were considered to be more reliable. There are 129 observations from double sources, correlation 0.89 .

\section{FDI Stock data:}

FDI Stock data are taken from the OECD Compendium. Instead of the year 1998, the year 1997 is taken. There are still plenty of missing values for 1997. The data are separate from inward FDI sources and outward FDI sources and an FDI stock of a host country in a home country usually differs depending on the source - host-country inward FDI or homecountry outward FDI data. Some values are negative. The coverage is limited to OECD-home countries in the outward FDI database and to OECD host countries in the inward FDI database. The merger of the two databases also yields a fairly broad coverage of non-OECD countries. All values are in Mill USD, using average annual exchange rates and a US deflator with the base year 1990. We find a correlation of 0.91 for the 448 observations for which we have information both from inward FDI and outward FDI data-sources. This indicates a substantial measurement error of FDI stock data, which may be due to different balance sheet and current account rules across countries or exchange rate effects. We calculate our FDI stock variable as a simple average of the two data-sources. There are 58 home countries and 57 hostcountries in the dataset, respectively.

FDIstock deflated by GDP deflator of US, with the base year 1990 (OECD Economic Outlook, 2000).

\section{Control Variables:}

Share of skilled labor: obtained from ILO, Yearbook of Labour Statistics, various years (data for US FDI obtained from Markusen and Maskus, 2001). Ratio of workers of occupational category 0/1 and 2 according to ISCO68, relative to the total number of workers. If there is a switch in the reporting of a country from ISCO68 to ISCO88, then an adjustment is made for all observations reporting according to ISCO88. The growth rate of the employment share of occupational categories 1,2 and 3 according to ISCO88 is calculated over the year, when the break in reporting occurs, to the year considered. Then, the last year before the break of reporting is multiplied by one plus this growth rate to yield the adjusted ISCO68 estimated for the year considered. If observations are only available according to ISCO88, then these observations are multiplied by the factor 0.69 . This factor is obtained from observations on those countries, for which a change in reporting occurred, by calculating the average ratio of skilled labor according to ISCO68 and ISCO88 observations for the consecutive years when the break in reporting occurs. Occasionally, another year close by was chosen if there would otherwise be missing observations. Sweden does not report category 2, ISCO68, separately from category 3 in the year 1994; Hence, category 3 is included in 1994; Another structural break occurs in 1998, when Statistic Sweden switches its reporting to ISCO88;

Investment cost: Data source is World Economic Forum and data were partially obtained from Carr et al. (2001) and missing data were supplemented by own construction from the original source wherever available. Survey data with index range $0-100(0=$ low cost). Composed of the unweighted average of answer scale to 10 questions that are related to obstacles to conducting FDI in a country. See Carr et al. (2001) for more information.

Protection: Obtained from World Economic Forum. Composed of the unweighted average of answer scale to 2 questions related to trade protection. See Carr et al. (2001) for more information.

Neighbor: Dummy variable with value 1 if a home country is the neighbor of a host country.

GDP data are obtained from World Development Indicators. 


\section{Summary Statistics}

Table A1: Summary statistics

\begin{tabular}{|c|c|c|c|c|c|}
\hline Variable & No of Obs. & Mean & Std. Dev & Min & Max \\
\hline SALES & 1431 & 7.27 & 23.16 & 0 & 324.13 \\
\hline FDI STOCK & 2229 & 2532.58 & 8903.19 & -1040.31 & 131988.30 \\
\hline$S U M G D P$ & 2765 & 2156.55 & 2399.60 & 14.71 & 13342.62 \\
\hline$S_{Z I Z E_{i}}$ & 2353 & 0.72 & 0.43 & 0.01 & 1.40 \\
\hline$S K I L L_{i}$ & 2353 & 1.20 & 0.90 & 0.12 & 13.00 \\
\hline INTER & 2353 & 0.81 & 0.54 & 0.0048 & 5.14 \\
\hline INTERPROT $_{i}$ & 2287 & 90.32 & 401.32 & 0.42 & 8567.77 \\
\hline$P_{R O T}$ & 2709 & 29.61 & 13.84 & 6.80 & 85.08 \\
\hline$P_{R O T}$ & 2659 & 29.55 & 13.84 & 6.80 & 85.08 \\
\hline$I N V C_{j}$ & 2659 & 34.57 & 11.58 & 12.5 & 79.43 \\
\hline DIST & 2880 & 6213.70 & 4846.28 & 174.02 & 19007.46 \\
\hline ADJACENT & 3332 & 0.14 & 0.34 & 0 & 1 \\
\hline
\end{tabular}




\section{B. Tables and diagrams}

Table 1: Summarizing previous empirical results on the $\mathrm{KC}$-model

\begin{tabular}{|c|c|c|c|c|}
\hline & Functional Form: & Sample coverage: & Skill data: & $\begin{array}{l}\text { Evidence for } \\
\text { the KC-model: }\end{array}$ \\
\hline $\begin{array}{l}\text { Carr, Markusen } \\
\text { and Maskus (2001) }\end{array}$ & $\begin{array}{l}\text { Indirect estimation } \\
\text { of Edgeworth box } \\
\text { (CMM-functional } \\
\text { form) }\end{array}$ & $\begin{array}{l}\text { US inward and } \\
\text { outward FDI (BEA) }\end{array}$ & $\begin{array}{l}\text { ILO data on the } \\
\text { total number of } \\
\text { skilled labor }\end{array}$ & Yes \\
\hline $\begin{array}{l}\text { Markusen and } \\
\text { Maskus (1999) }\end{array}$ & Ibid & Ibid & Ibid & $\begin{array}{l}\text { Mixed } \\
\text { (No support in } \\
\text { outward US } \\
\text { sample) }\end{array}$ \\
\hline $\begin{array}{l}\text { Markusen and } \\
\text { Maskus (2001) }\end{array}$ & Ibid & Ibid & Ibid & $\begin{array}{l}\text { No } \\
\text { (Rejection } \\
\text { in favor of } \\
\text { Horizontal model) }\end{array}$ \\
\hline $\begin{array}{l}\text { Blonigen, Davies } \\
\text { and Head (2002) }\end{array}$ & $\begin{array}{l}\text { Absolute value } \\
\text { specification on } \\
\text { CMM-functional } \\
\text { form }\end{array}$ & $\begin{array}{l}\text { 1. US inward and } \\
\text { outward FDI (BEA) } \\
\text { 2. FDI stocks (OECD) }\end{array}$ & $\begin{array}{l}\text { 1. ILO data on the total } \\
\text { number of skilled labor } \\
\text { 2. Mean years of } \\
\text { schooling from } \\
\text { Barro and Lee (1996) }\end{array}$ & $\begin{array}{l}\text { No } \\
\text { (Rejection } \\
\text { in favor of } \\
\text { Horizontal model) }\end{array}$ \\
\hline Davies (2002) & $\begin{array}{l}\text { Third-order } \\
\text { polynomial on } \\
\text { CMM-functional } \\
\text { form }\end{array}$ & $\begin{array}{l}\text { 1. US inward and } \\
\text { outward FDI (BEA) } \\
\text { 2. US inward and } \\
\text { outward FDI (BEA) }\end{array}$ & $\begin{array}{l}\text { 1.ILO data on the } \\
\text { number of skilled labor } \\
2 \text { Mean years of } \\
\text { schooling } \\
\text { (Barro and Lee (1996)) }\end{array}$ & $\begin{array}{l}\text { Mixed } \\
\text { (Evidence } \\
\text { only in } \\
\text { sample (3)) }\end{array}$ \\
\hline $\begin{array}{l}\text { Braconier, } \\
\text { Norbäck and } \\
\text { Urban }(\mathbf{2 0 0 2})[\end{array}$ & $\begin{array}{l}\text { CMM-functional } \\
\text { form }\end{array}$ & $\begin{array}{l}\text { 3. FDI stocks (OECD) } \\
\text { US and Swedish } \\
\text { outward FDI (BEA } \\
\text { and IUI) }\end{array}$ & $\begin{array}{l}\text { 3. Ibid } \\
\text { Relative wage premium } \\
\text { for host country skilled } \\
\text { labor (UBS) }\end{array}$ & $\begin{array}{l}\text { Yes } \\
\text { (Evidence from } \\
\text { wage data) }\end{array}$ \\
\hline $\begin{array}{l}\text { Braconier, } \\
\text { Norbäck and } \\
\text { Urban }\end{array}$ & $\begin{array}{l}\text { Direct estimation } \\
\text { on the Edgeworth } \\
\text { box (BNU- } \\
\text { specification) }\end{array}$ & $\begin{array}{l}\text { 1. Enlarged OECD data } \\
\text { ( } 56 \text { home and } 85 \text { host } \\
\text { countries) } \\
\text { 2. FDIstock (OECD) }\end{array}$ & $\begin{array}{l}\text { 1.ILO data on the } \\
\text { number of skilled labor } \\
\text { 2. ILO data on the } \\
\text { number of skilled labor } \\
\text {-Relative wage premium } \\
\text { for host country skilled } \\
\text { labor (UBS). } \\
\text {-Mean years of schooling } \\
\text { (Barro and Lee (1996)) }\end{array}$ & Yes \\
\hline
\end{tabular}


Table 2 : Defining the CMM-specification and the BNU-specification (1) of the KC model.

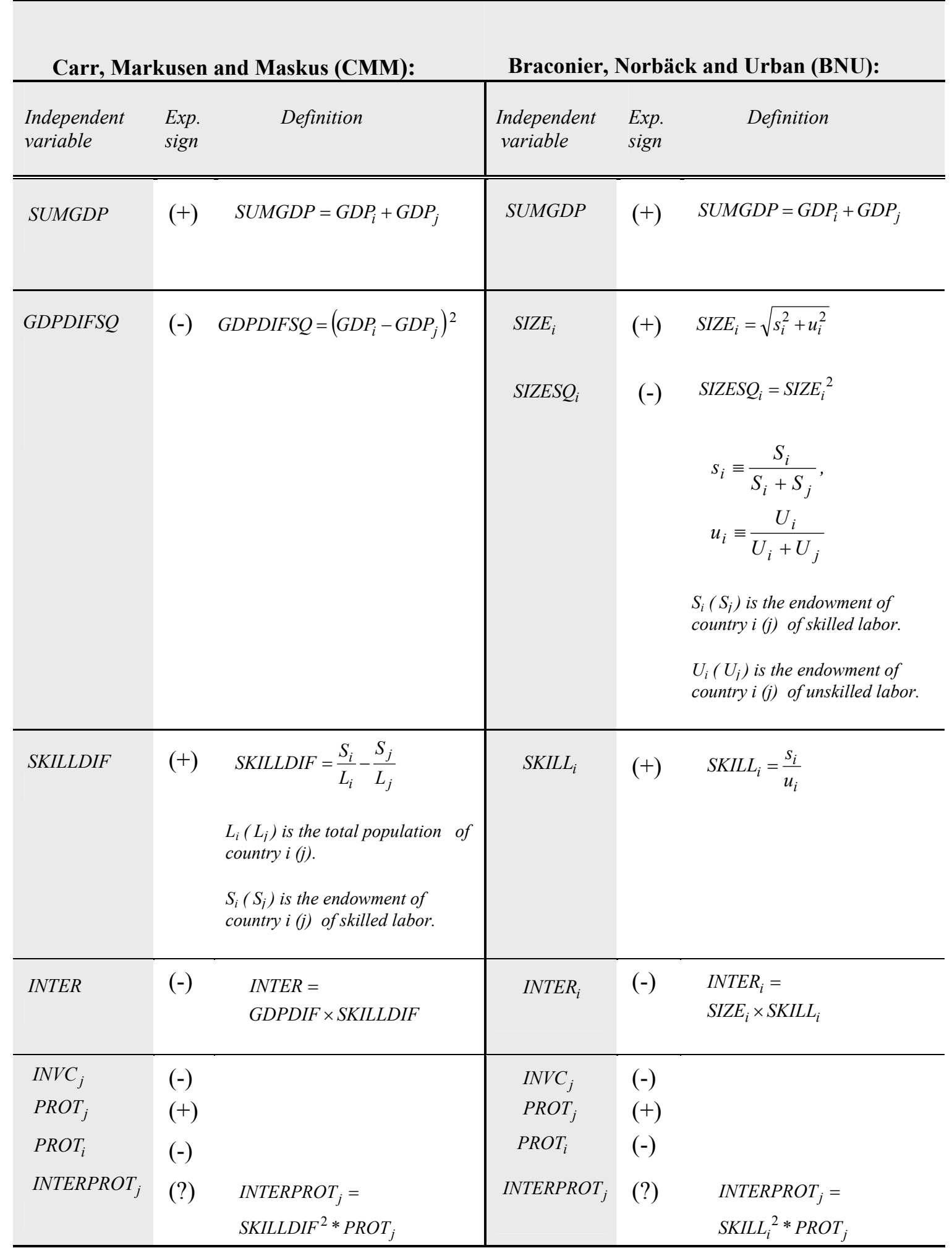

Note: Exp. Sign denotes expected sign. 
Table 3: Estimating the BNU-specification (1)

\begin{tabular}{|c|c|c|c|c|c|c|c|}
\hline & \multicolumn{4}{|c|}{ Sales } & \multicolumn{2}{|c|}{ FDI stock } & \multirow[b]{3}{*}{$\begin{array}{c}\text { Expected } \\
\text { Sign }\end{array}$} \\
\hline & (i): & (ii): & (iii): & (iii): & (v): & (vi): & \\
\hline & OLS & FE & $\begin{array}{l}\text { FE, } \\
\text { SKILL > } 1\end{array}$ & $\begin{array}{l}\text { FE, } \\
\text { SKILL } \leq 0\end{array}$ & OLS & FE & \\
\hline$S U M G D P$ & $\begin{array}{l}6.2 \times 10^{-3 * * * *} \\
(7.42)\end{array}$ & $\begin{array}{l}4.3 \times 10^{-3} \\
(1.11)\end{array}$ & $\begin{array}{l}3.4 \times 10^{-3} \\
(1.56)\end{array}$ & $\begin{array}{l}0.01 \\
(0.82)\end{array}$ & $\begin{array}{c}2.20 * * * \\
(8.07)\end{array}$ & $\begin{array}{l}3.36 * * * \\
(2.99)\end{array}$ & + \\
\hline$S I Z E_{i}$ & $\begin{array}{l}81.55 * * * \\
(5.51)\end{array}$ & $\begin{array}{l}93.90 * * * \\
(5.54)\end{array}$ & $\begin{array}{l}50.71 * * * \\
(3.86)\end{array}$ & $\begin{array}{l}159.12 * * * \\
(5.07)\end{array}$ & $\begin{array}{l}2.1 \times 10^{4 * * *} \\
(5.16)\end{array}$ & $\begin{array}{l}2.9 \times 10^{4 * * * *} \\
(4.75)\end{array}$ & + \\
\hline$S I Z E S Q_{i}$ & $\begin{array}{l}-49.30^{* * * *} \\
(-5.34)\end{array}$ & $\begin{array}{l}-67.77 * * * \\
(-4.62)\end{array}$ & $\begin{array}{l}-35.02 * * * \\
(-4.26)\end{array}$ & $\begin{array}{l}-73.16^{* * * *} \\
(-3.64)\end{array}$ & $\begin{array}{l}-1.2 \times 10^{4 * * * *} \\
(-5.02)\end{array}$ & $\begin{array}{l}-1.6 \times 10^{4} * * * \\
(-4.74)\end{array}$ & - \\
\hline$S K I L L_{i}$ & $\begin{array}{l}6.04 * * * \\
(3.88)\end{array}$ & $\begin{array}{l}17.79 * * * \\
(5.04)\end{array}$ & $\begin{array}{l}7.06 * * * \\
(3.41)\end{array}$ & $\begin{array}{l}92.08 * * * \\
(4.06)\end{array}$ & $\begin{array}{l}2.5 \times 10^{3 * * *} \\
(4.30)\end{array}$ & $\begin{array}{l}6.9 \times 10^{3 * * * *} \\
(5.31)\end{array}$ & + \\
\hline$I_{N T E R_{i}}$ & $\begin{array}{l}-13.88 * * * \\
(-4.06)\end{array}$ & $\begin{array}{l}-20.14 * * * \\
(-3.78)\end{array}$ & $\begin{array}{l}-4.45 \\
(-1.36)\end{array}$ & $\begin{array}{l}-113.44 * * * \\
(-3.55)\end{array}$ & $\begin{array}{l}-3.4 \times 10^{3 * * *} \\
(-3.49)\end{array}$ & $\begin{array}{l}-9.8 \times 10^{4} * * * \\
(-4.79)\end{array}$ & - \\
\hline$I N V C_{j}$ & $\begin{array}{l}-0.27 * * * \\
(-3.76)\end{array}$ & $\begin{array}{l}-0.17 \\
(-0.87)\end{array}$ & $\begin{array}{l}0.14 \\
(0.92)\end{array}$ & $\begin{array}{l}-0.75^{*} \\
(-1.69)\end{array}$ & $\begin{array}{l}-1.1 \times 10^{2} * * * \\
(-4.75)\end{array}$ & $\begin{array}{l}68.79 \\
(1.16)\end{array}$ & - \\
\hline$P_{R O T}$ & $\begin{array}{l}-0.11^{*} \\
(-1.92)\end{array}$ & $\begin{array}{l}0.15^{*} \\
(1.74)\end{array}$ & $\begin{array}{l}0.03 \\
(0.50)\end{array}$ & $\begin{array}{l}0.67 * \\
(1.90)\end{array}$ & $\begin{array}{l}-15.22 \\
(-0.97)\end{array}$ & $\begin{array}{l}5.48 \\
(0.25)\end{array}$ & + \\
\hline$I_{N T E R P R O T}$ & $\begin{array}{l}4.1 \times 10^{-4} \\
(0.23)\end{array}$ & $\begin{array}{l}-0.01 * * * \\
(-2.69)\end{array}$ & $\begin{array}{l}-3.5 \times 10^{-3} * * \\
(-2.16)\end{array}$ & $\begin{array}{l}-0.79 * * \\
(-2.13)\end{array}$ & $\begin{array}{l}-1.86^{* * *} \\
(-2.50)\end{array}$ & $\begin{array}{l}-6.94 * * * \\
(-4.51)\end{array}$ & $?$ \\
\hline$P_{R O T}$ & $\begin{array}{l}-0.07 \\
(-1.15)\end{array}$ & $\begin{array}{l}0.07 \\
(0.50)\end{array}$ & $\begin{array}{l}-0.134 \\
(-1.19)\end{array}$ & $\begin{array}{l}0.01 \\
(0.04)\end{array}$ & $\begin{array}{l}-53.96^{* * * *} \\
(-4.57)\end{array}$ & $\begin{array}{l}29.73 \\
(1.23)\end{array}$ & - \\
\hline DIST & $\begin{array}{l}-8.8 \times 10^{-4 * * * *} \\
(-7.86)\end{array}$ & $\begin{array}{l}-9.3 \times 10^{-4 * * * *} \\
(-2.87)\end{array}$ & $\begin{array}{l}-1.4 \times 10^{-3 * * * *} \\
(-4.40)\end{array}$ & $\begin{array}{l}-9.8 \times 10^{-4} \\
(-1.30)\end{array}$ & $\begin{array}{l}-0.25 * * * \\
(-7.45)\end{array}$ & $\begin{array}{l}-0.40^{*} \\
(-6.94)\end{array}$ & $?$ \\
\hline CONST & $\begin{array}{l}-5.43 \\
(-1.01)\end{array}$ & $\begin{array}{l}-30.37 * * \\
(-2.22)\end{array}$ & $\begin{array}{l}-5.32 \\
(-0.28)\end{array}$ & $\begin{array}{l}-1.0 \times 10^{2 * * * *} \\
(-2.79)\end{array}$ & $\begin{array}{l}-1.7 \times 10^{3} \\
(-1.20)\end{array}$ & $\begin{array}{l}-2.2 \times 10^{4 * * * *} \\
(-3.86)\end{array}$ & \\
\hline Obs & 1122 & 1122 & 615 & 507 & 1796 & 1796 & \\
\hline Adj R2 & 0.30 & 0.36 & 0.51 & 0,47 & 0.26 & 0.36 & \\
\hline
\end{tabular}


Table 4: Extensions of the BNU-specification (1)

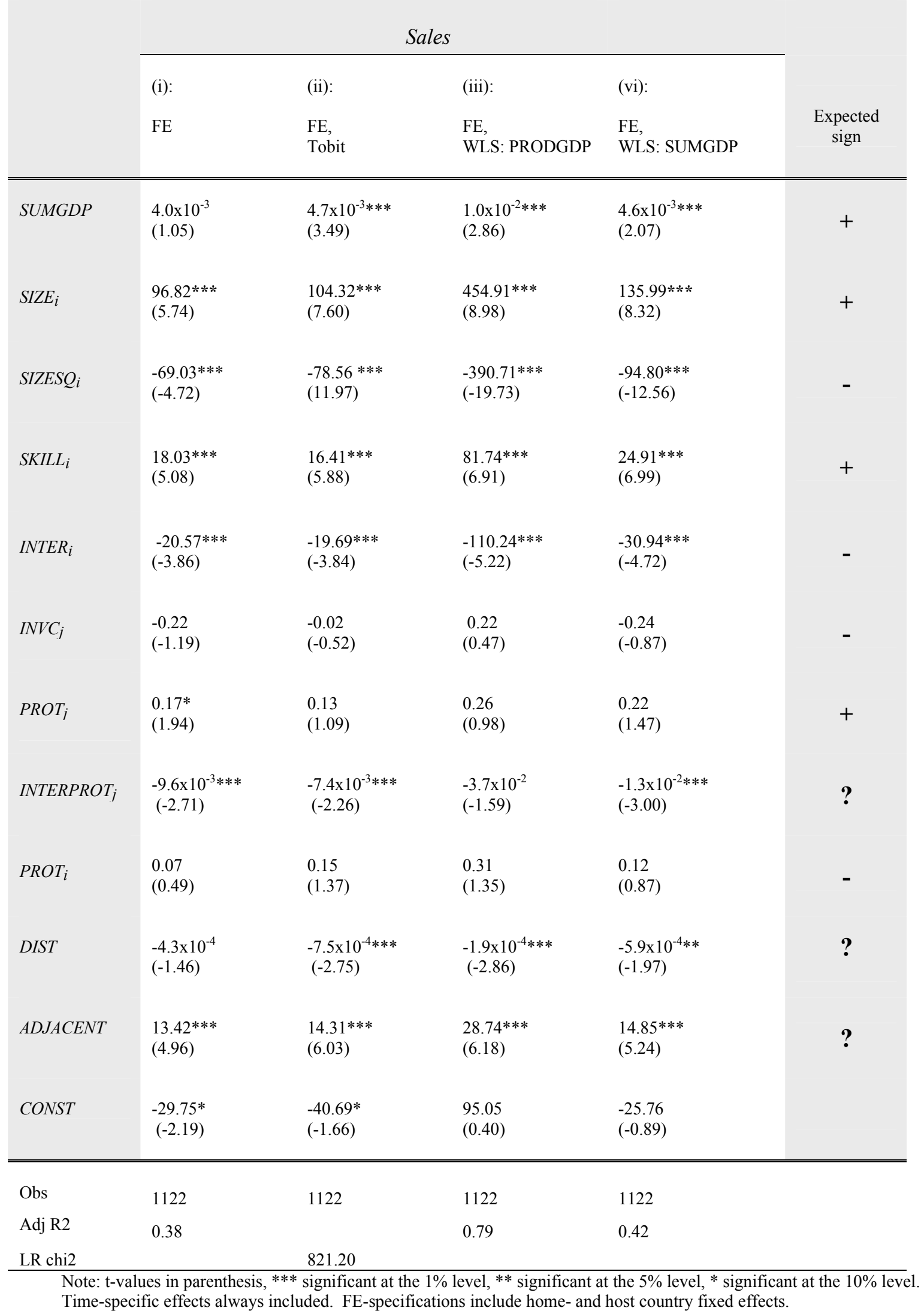


Table 5: Testing the KC-model against the Horizontal- and the Vertical model

\begin{tabular}{|c|c|c|c|c|c|c|}
\hline & \multicolumn{3}{|c|}{ Sales } & \multicolumn{3}{|c|}{ Expected sign } \\
\hline & $\begin{array}{l}\text { (i) } \\
\text { OLS }\end{array}$ & $\begin{array}{l}\text { (ii) } \\
\text { OLS }\end{array}$ & $\begin{array}{l}\text { (iii) } \\
\text { OLS }\end{array}$ & $\mathrm{KC}$ & HOR & VER \\
\hline$S U M G D P$ & $\begin{array}{l}6.1 \times 10^{-3} * * * \\
(7.30)\end{array}$ & $\begin{array}{l}0.01 * * * \\
(4.39)\end{array}$ & $\begin{array}{l}0.01 * * * \\
(4.38)\end{array}$ & + & + & $\mathbf{0}$ \\
\hline$S I Z E_{i}$ & $\begin{array}{l}82.76^{* * * *} \\
(5.63)\end{array}$ & $\begin{array}{l}89.88 * * * \\
(5.49)\end{array}$ & $\begin{array}{l}8989 * * * \\
(5.48)\end{array}$ & + & + & $\mathbf{0}$ \\
\hline SIZESQ $_{i}$ & $\begin{array}{l}-50.10^{* * *} \\
(-5.44)\end{array}$ & $\begin{array}{l}-51.58 * * * \\
(-5.66)\end{array}$ & $\begin{array}{l}-51.57 * * * \\
(-5.66)\end{array}$ & - & - & $\mathbf{0}$ \\
\hline$S K I L L_{i}$ & $\begin{array}{l}6.49 * * * \\
(4.10)\end{array}$ & $\begin{array}{l}16.29 * * * \\
(3.62)\end{array}$ & $\begin{array}{l}16.29 * * * \\
(3.61)\end{array}$ & + & + & + \\
\hline$S_{K I L L S Q}$ & $\begin{array}{l}-0.16 \\
(-0.14)\end{array}$ & $\begin{array}{l}-0.70 * * \\
(-2.45)\end{array}$ & $\begin{array}{l}-0.69 \\
(-1.46)\end{array}$ & $?$ & - & ? \\
\hline$I N T E R_{i}$ & $\begin{array}{l}-13.82 * * * \\
(-4.15)\end{array}$ & $\begin{array}{l}-16.27 * * * \\
(-3.68)\end{array}$ & $\begin{array}{l}-16.28 * * * \\
(-3.72)\end{array}$ & - & $\mathbf{0}$ & - \\
\hline INTSUM & & $\begin{array}{l}-4.2 \times 10^{-3 * * *} \\
(-2.58)\end{array}$ & $\begin{array}{l}-4.2 \times 10^{-3 *} \\
(-2.58)\end{array}$ & - & - & + \\
\hline$I_{N T E R P R O T}$ & & & $\begin{array}{l}-9.5 \times 10^{-5} \\
(-0.02)\end{array}$ & $?$ & $?$ & $?$ \\
\hline$I N V C_{j}$ & $\begin{array}{l}-0.26 * * * \\
(-3.73)\end{array}$ & $\begin{array}{l}-0.28 * * * \\
(-4.00)\end{array}$ & $\begin{array}{l}-0.28 \\
(-3.99)\end{array}$ & - & - & - \\
\hline PROTj & $\begin{array}{l}-0.11 * * \\
(-2.10)\end{array}$ & $\begin{array}{l}-0.04 \\
(-0.90)\end{array}$ & $\begin{array}{l}-0.04 \\
(-0.86)\end{array}$ & + & + & + \\
\hline PROTi & $\begin{array}{l}-0.62 \\
(-0.98)\end{array}$ & $\begin{array}{l}-0.08 \\
(-1.44)\end{array}$ & $\begin{array}{l}-0.08 \\
(-1.44)\end{array}$ & - & - & - \\
\hline ADJACENT & $\begin{array}{l}12.47 * * * \\
(4.70)\end{array}$ & $\begin{array}{l}12.44 * * * \\
(4.60)\end{array}$ & $\begin{array}{l}12.44 * * * \\
(4.97)\end{array}$ & $?$ & $?$ & $?$ \\
\hline DIST & $\begin{array}{l}-5.99 \times 10^{-4} * * * \\
(-6.21)\end{array}$ & $\begin{array}{l}-6.4 \times 10^{-4 * * * *} \\
(-6.14)\end{array}$ & $\begin{array}{l}-6.4 \times 10^{-4} * \\
(-5.14)\end{array}$ & $?$ & $?$ & $?$ \\
\hline CONST & $\begin{array}{l}-9.56^{*} \\
(-1.85)\end{array}$ & $\begin{array}{l}-22.85 * * * \\
(-2.60)\end{array}$ & $\begin{array}{l}-22.86 \\
(-4.60)\end{array}$ & & & \\
\hline $\begin{array}{l}\text { Obs } \\
\text { Adj R2 }\end{array}$ & $\begin{array}{l}1122 \\
0.32\end{array}$ & $\begin{array}{l}1122 \\
0.35\end{array}$ & $\begin{array}{l}1122 \\
0.35\end{array}$ & & & \\
\hline
\end{tabular}

Note: t-values in parenthesis, ${ }^{* * *}$ significant at the $1 \%$ level, ${ }^{* *}$ significant at the $5 \%$ level, $*$ significant at the $10 \%$ level Time-specific effects included. KC denotes the KC-model, VER denotes the Vertical model and HOR denotes the Horizontal model. 
Table 6: Re-estimating the CMM (2001)

\begin{tabular}{|c|c|c|c|c|c|c|c|}
\hline & \multicolumn{4}{|c|}{ Sales } & \multicolumn{2}{|c|}{ FDI stocks } & \multirow[b]{3}{*}{ Exp. sign } \\
\hline & (i): & (ii): & (iii): & (iv) & $(\mathrm{v})$ : & (vi): & \\
\hline & OLS & $\mathrm{FE}$ & $\begin{array}{l}\text { FE, } \\
\text { SKILLDIF >0 }\end{array}$ & $\begin{array}{l}\text { FE, } \\
\text { SKILLDIF } \leq 0\end{array}$ & OLS & $\mathrm{FE}$ & \\
\hline$S U M G D P$ & $\begin{array}{l}0.01 * * * \\
(5.58)\end{array}$ & $\begin{array}{l}0.03 * * * \\
(4.14)\end{array}$ & $\begin{array}{l}0.01 * * * \\
(3.35)\end{array}$ & $\begin{array}{l}0.04 * * * \\
(8.78)\end{array}$ & $\begin{array}{l}4.02 * * * \\
(5.77)\end{array}$ & $\begin{array}{l}11.06^{* * * *} \\
(5.59)\end{array}$ & + \\
\hline GDPDIFSQ & $\begin{array}{l}-1.4 \times 10^{-6 * * * *} \\
(3.98)\end{array}$ & $\begin{array}{l}-2.3 \times 10^{-6 * * * *} \\
(-4.53)\end{array}$ & $\begin{array}{l}-6.6 \times 10^{-7} * * * \\
(-3.27)\end{array}$ & $\begin{array}{l}4.0 \times 10^{-6 * * *} \\
(-12.37)\end{array}$ & $\begin{array}{l}-3.7 \times 10^{-4} * * * \\
(-3.22)\end{array}$ & $\begin{array}{l}-7.6 \times 10^{4 * * *} \\
(-4.67)\end{array}$ & - \\
\hline SKILLDIF & $\begin{array}{l}-6.56 \\
(-1.02)\end{array}$ & $\begin{array}{l}14.29 \\
(1.55)\end{array}$ & $\begin{array}{l}6.63 \\
(0.45)\end{array}$ & $\begin{array}{l}-19.56 \\
(-0.52)\end{array}$ & $\begin{array}{l}5.3 \times 10^{3 * * *} \\
(3.98)\end{array}$ & $\begin{array}{l}-4.1 \times 10^{2} \\
(-0.13)\end{array}$ & + \\
\hline INTER & $\begin{array}{l}4.0 \times 10^{-4} \\
(0.12)\end{array}$ & $\begin{array}{l}-0.01 * * * \\
(-4.56)\end{array}$ & $\begin{array}{l}-0.02 * * * \\
(-3.94)\end{array}$ & $\begin{array}{l}-0.01 * * \\
(-2.05)\end{array}$ & $\begin{array}{l}-2.13 \\
(-1.55)\end{array}$ & $\begin{array}{l}-9.43 * * * \\
(-4.93)\end{array}$ & - \\
\hline$I N V C_{j}$ & $\begin{array}{l}-0.10 \\
(-1.28)\end{array}$ & $\begin{array}{l}-0.11 \\
(-0.58)\end{array}$ & $\begin{array}{l}0.12 \\
(0.84)\end{array}$ & $\begin{array}{l}-0.14 \\
(-0.40)\end{array}$ & $\begin{array}{l}-1.0 \times 10^{2} * * * \\
(-4.50)\end{array}$ & $\begin{array}{l}81.28 \\
(1.42)\end{array}$ & - \\
\hline$P R O T_{j}$ & $\begin{array}{l}-0.18 * * \\
(-2.52)\end{array}$ & $\begin{array}{l}-0.02 \\
(-0.22)\end{array}$ & $\begin{array}{l}-0.06 \\
(-0.86)\end{array}$ & $\begin{array}{l}-0.24 \\
(-1.31)\end{array}$ & $\begin{array}{l}-15.41 \\
(-0.85)\end{array}$ & $\begin{array}{l}-6.61 \\
(-0.29)\end{array}$ & + \\
\hline$I_{N T E R P R O T}$ & $\begin{array}{l}2.45 * * * \\
(2.71)\end{array}$ & $\begin{array}{l}1.25^{*} \\
(1.84)\end{array}$ & $\begin{array}{l}1.45^{*} \\
(1.68)\end{array}$ & $\begin{array}{l}3.92 \\
(0.71)\end{array}$ & $\begin{array}{l}-2.9 \times 10^{2} \\
(-1.23)\end{array}$ & $\begin{array}{l}-1.4 \times 10^{3 * * *} \\
(-4.41)\end{array}$ & $?$ \\
\hline PROT $_{j}$ & $\begin{array}{l}-0.12 * * \\
(-2.22)\end{array}$ & $\begin{array}{l}-0.11 \\
(-1.00)\end{array}$ & $\begin{array}{l}-0.17 \\
(-1.62)\end{array}$ & $\begin{array}{l}-0.17 \\
(-1.19)\end{array}$ & $\begin{array}{l}-36.51 * * * \\
(-3.43)\end{array}$ & $\begin{array}{l}-1.99 \\
(-0.11)\end{array}$ & - \\
\hline$D I S T$ & $\begin{array}{l}-6.2 \times 10^{-4 * * *} \\
(-5.39)\end{array}$ & $\begin{array}{l}-1.2 \times 10^{-3} * * * \\
(-4.24)\end{array}$ & $\begin{array}{l}-1.4 \times 10^{-3} * * * \\
(-4.67)\end{array}$ & $\begin{array}{l}-1.6 \times 10^{-3 * *} \\
(-2.82)\end{array}$ & $\begin{array}{l}-0.21 * * * \\
(-6.75)\end{array}$ & $\begin{array}{l}-0.35 * * * \\
(-7.02)\end{array}$ & $?$ \\
\hline CONST & $\begin{array}{l}2.89 \\
(0.67)\end{array}$ & $\begin{array}{l}-6.73 \\
(-0.55)\end{array}$ & $\begin{array}{l}-15.47 \\
(-0.76)\end{array}$ & $\begin{array}{l}-4.01 \\
(-0.24)\end{array}$ & $\begin{array}{l}3.5 \times 10^{3 * * *} \\
(4.47)\end{array}$ & $\begin{array}{l}-1.1 \times 10^{4 * * *} \\
(-3.87)\end{array}$ & \\
\hline Obs & 1122 & 1122 & 615 & 507 & 1796 & 1796 & \\
\hline Adj R2 & 0.41 & 0.56 & 0.51 & 0.75 & 0.31 & 0.52 & \\
\hline
\end{tabular}




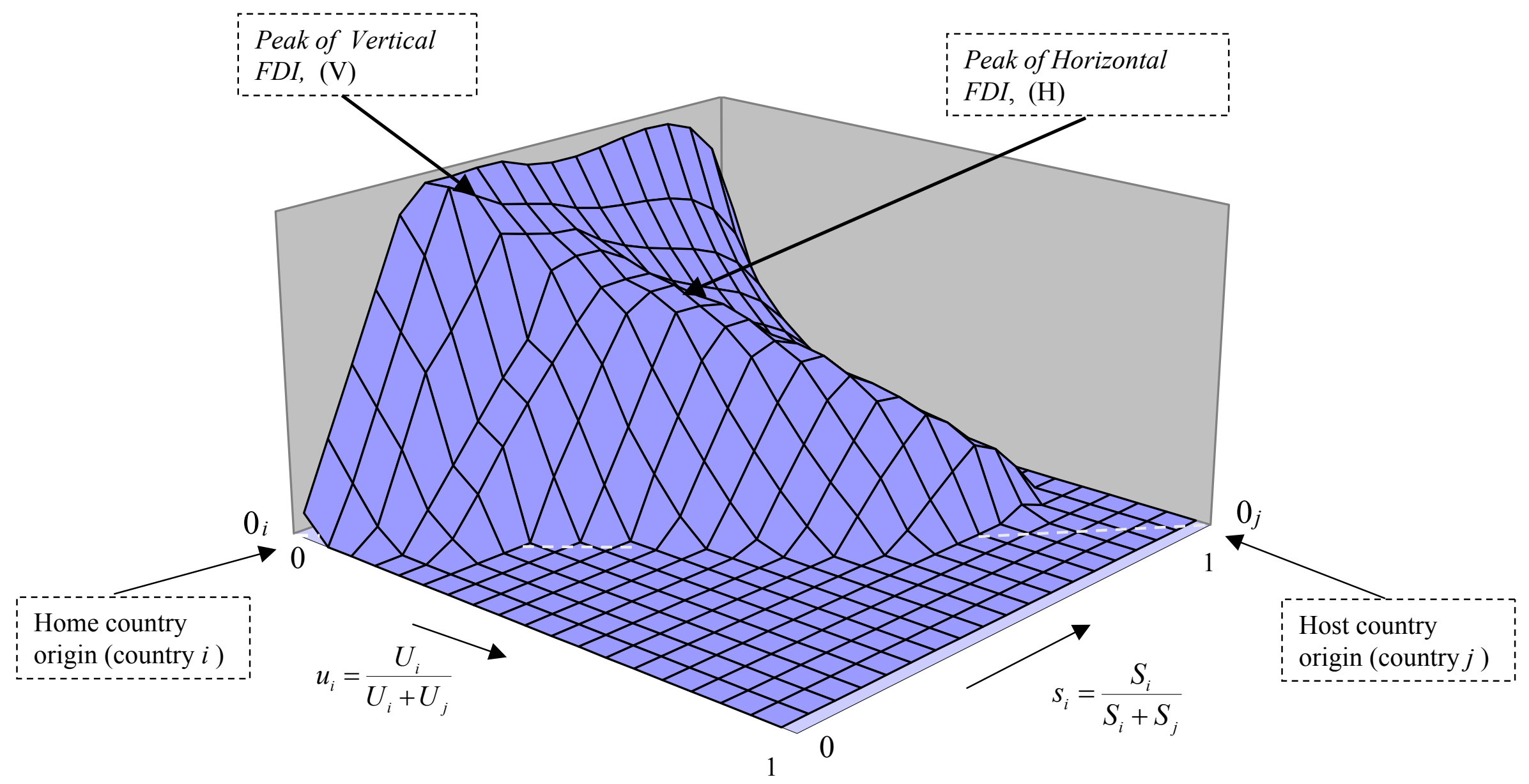

Figure 1: Simulated affiliate sales based on the KC model from Markusen (2002). 


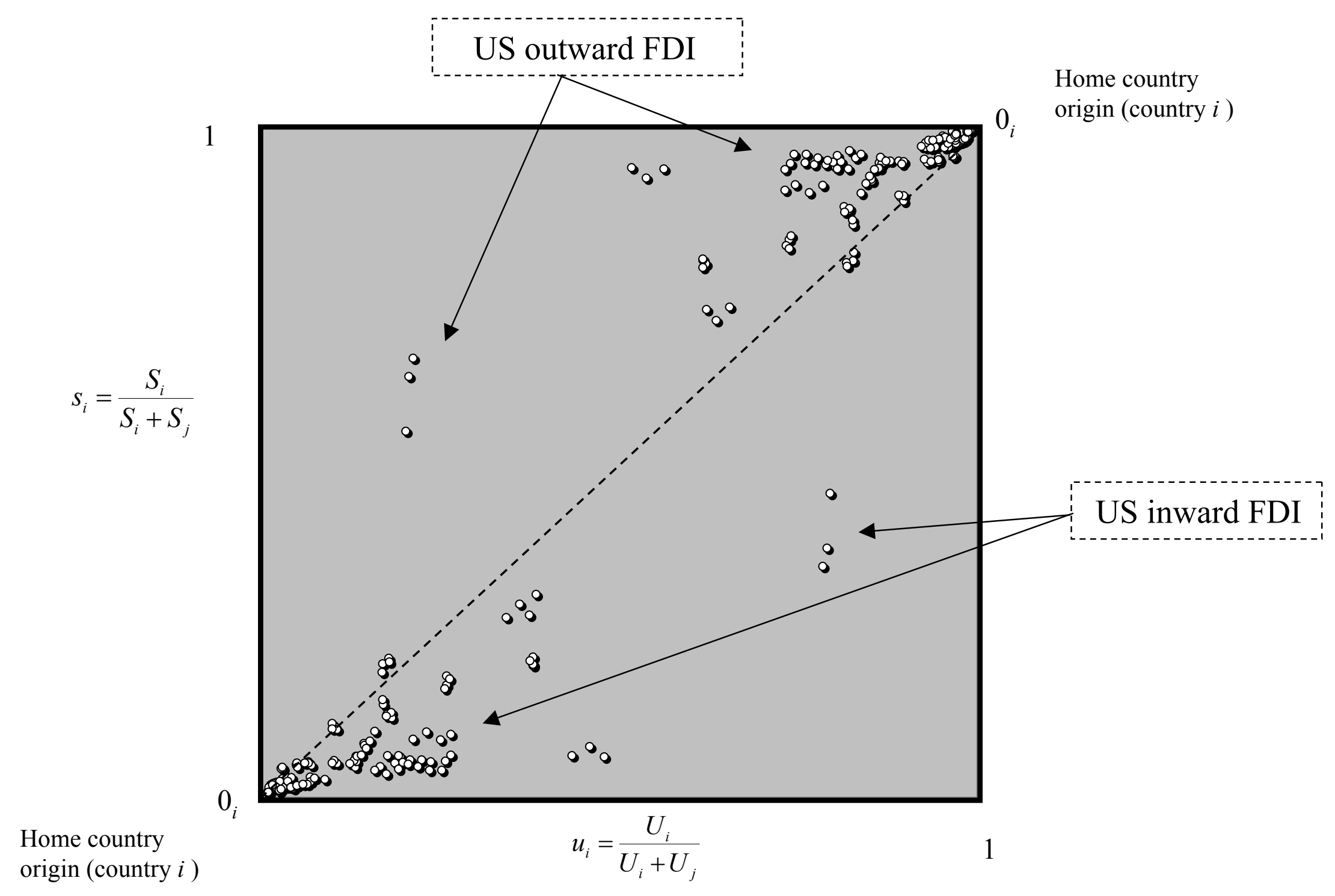

Figure 2: Illustrating the US inbound and US outbound sample in CMM 

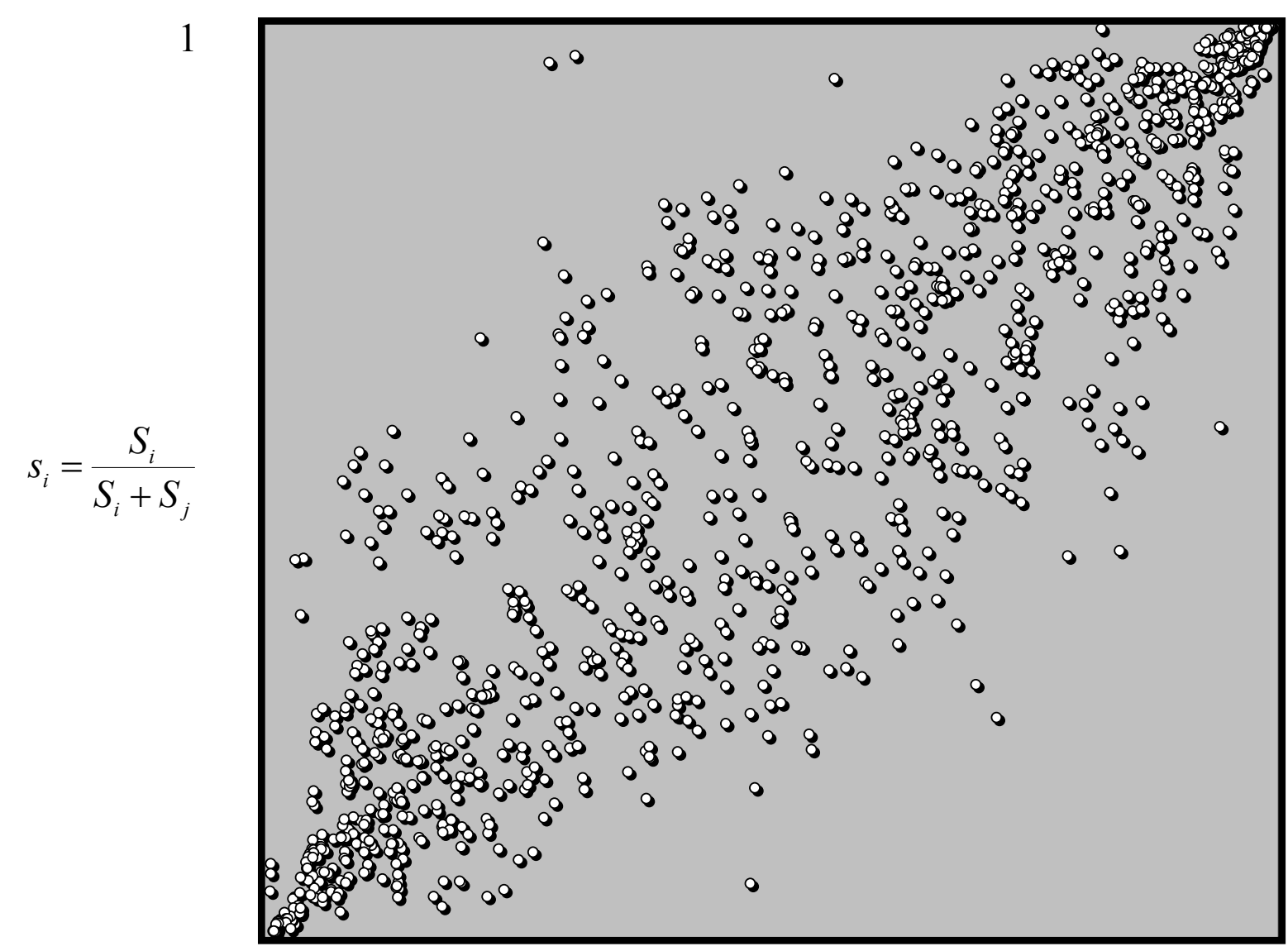

$0_{j} \quad$ origin (country $i$ )

Home country origin (country $i$ )

$$
u_{i}=\frac{U_{i}}{U_{i}+U_{j}}
$$

Figure 3: Illustrating the coverage of the extended sample on affiliates sales 


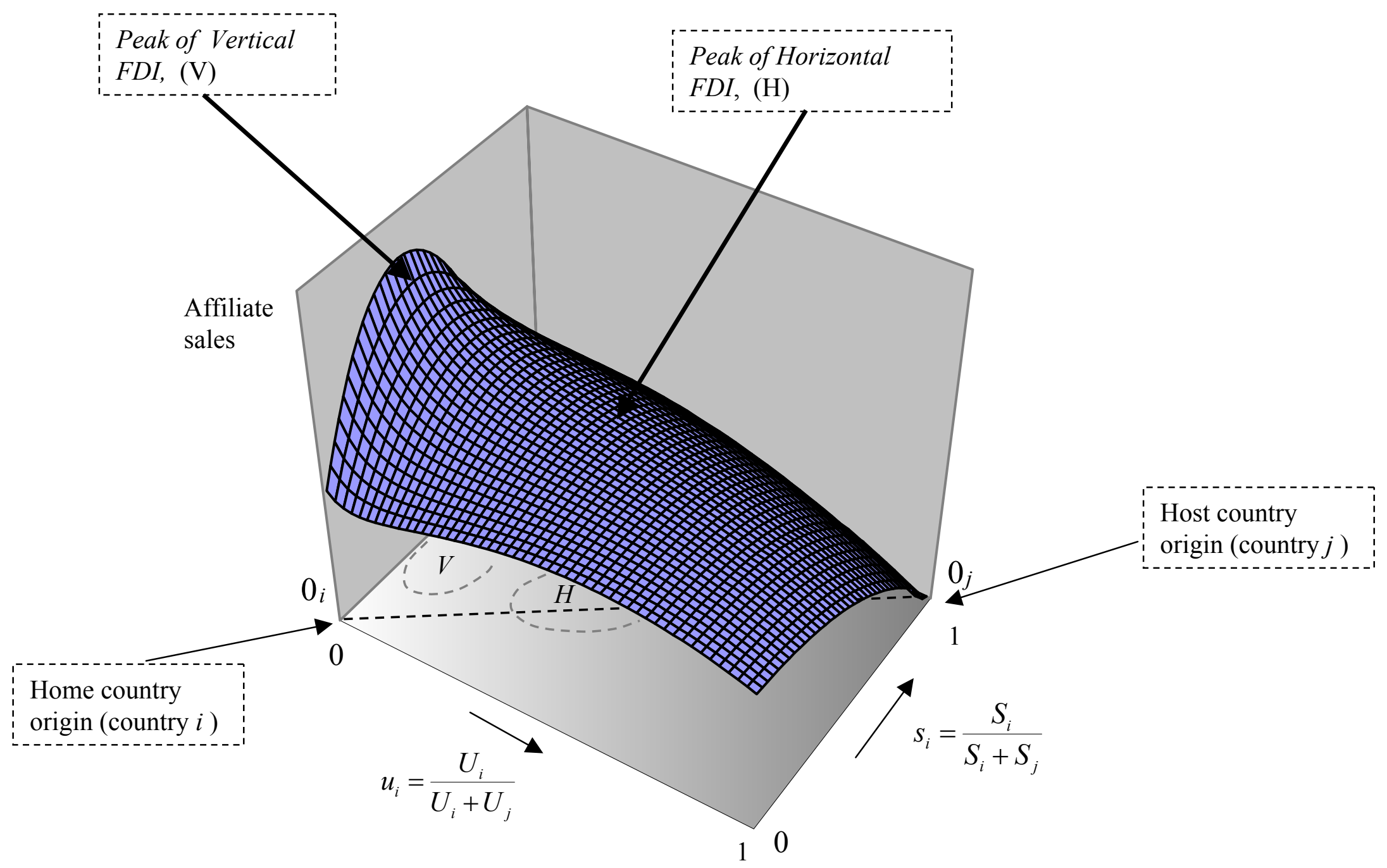

Figure 4: Illustrating predicted affiliate sales from (1) 


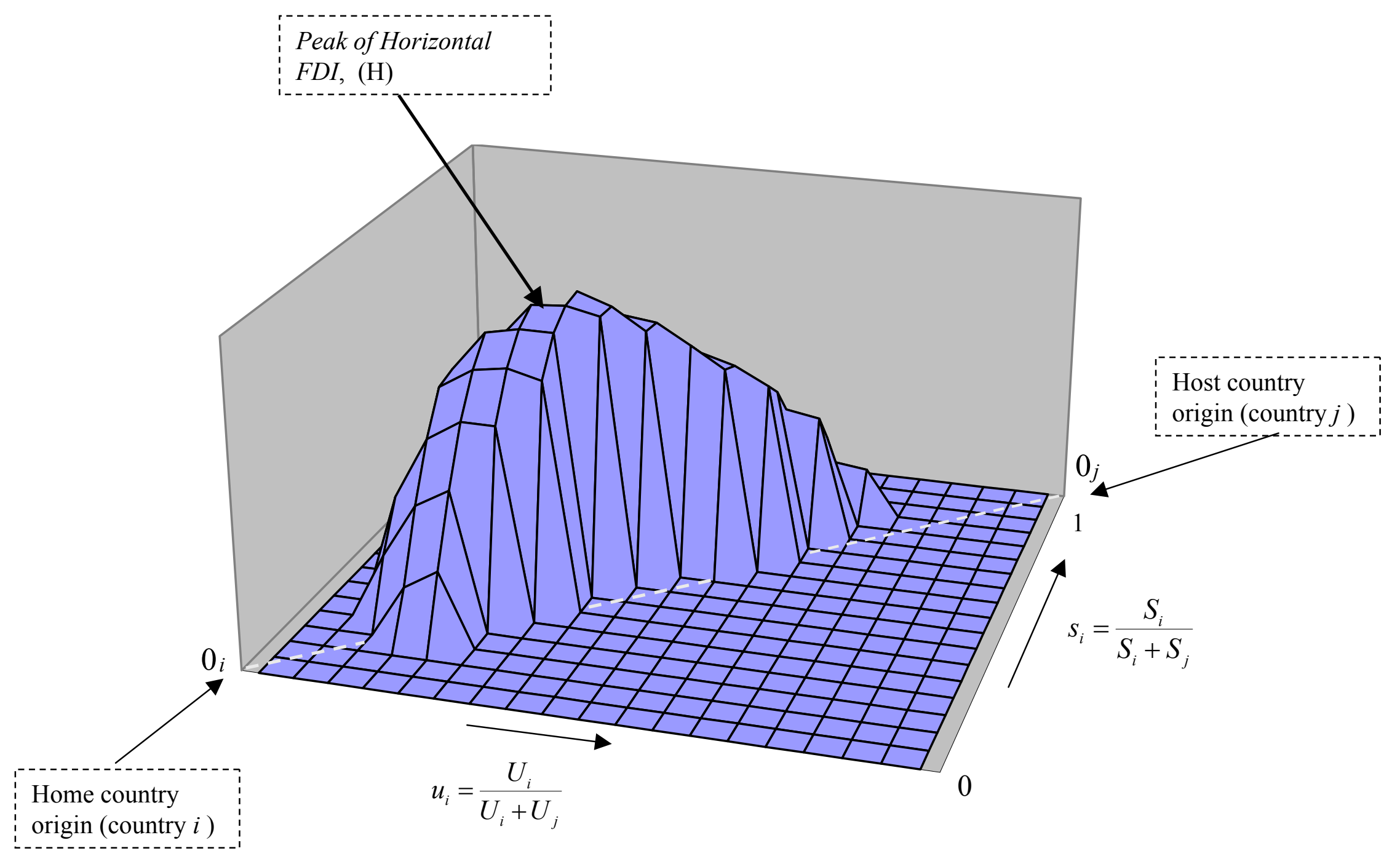

Figure 5: Simulated affiliate sales based on the Horizontal model from Markusen (2002). 


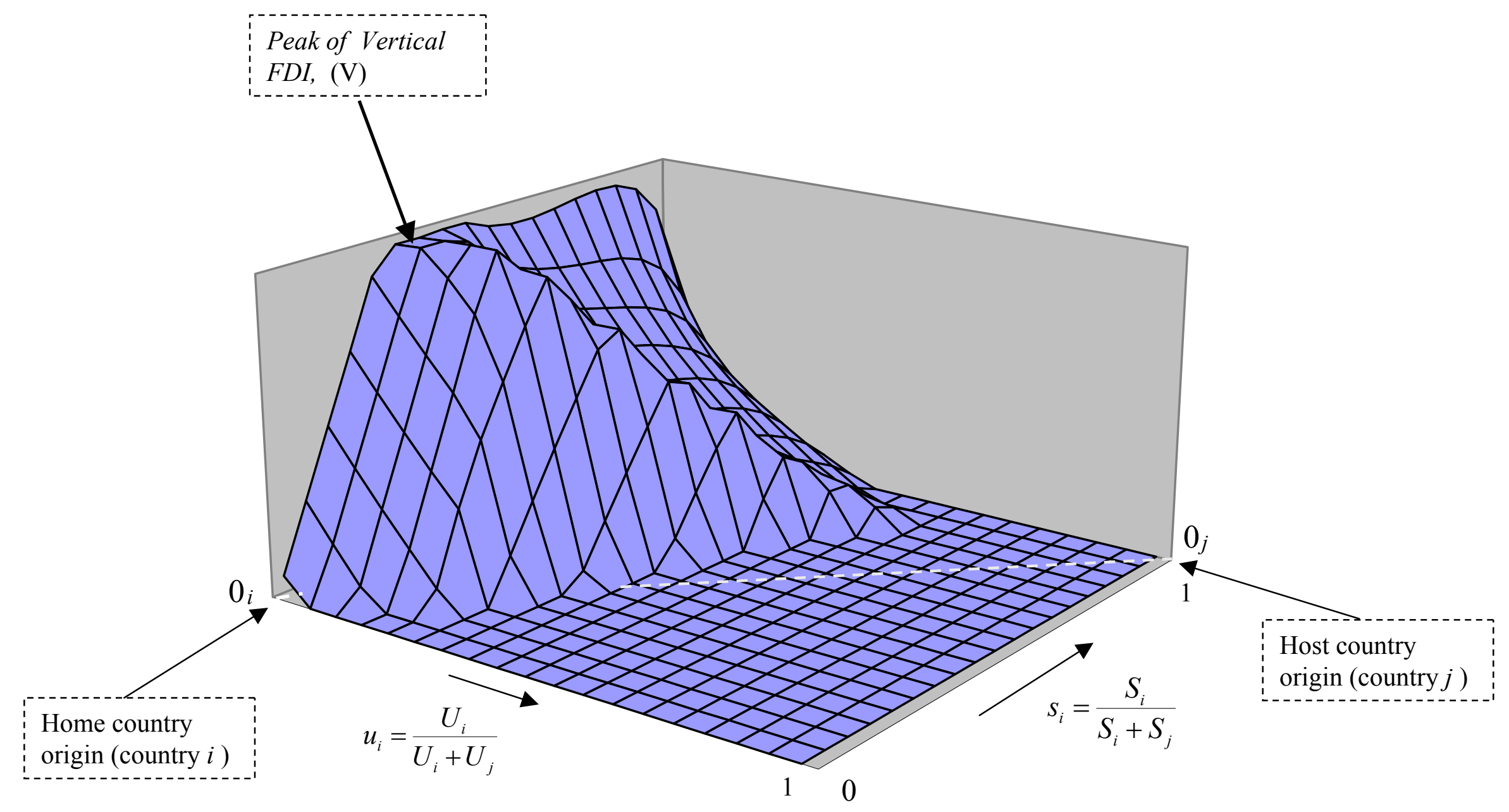

Figure 6: Simulated affiliate sales based on the Vertical model from Markusen (2002). 


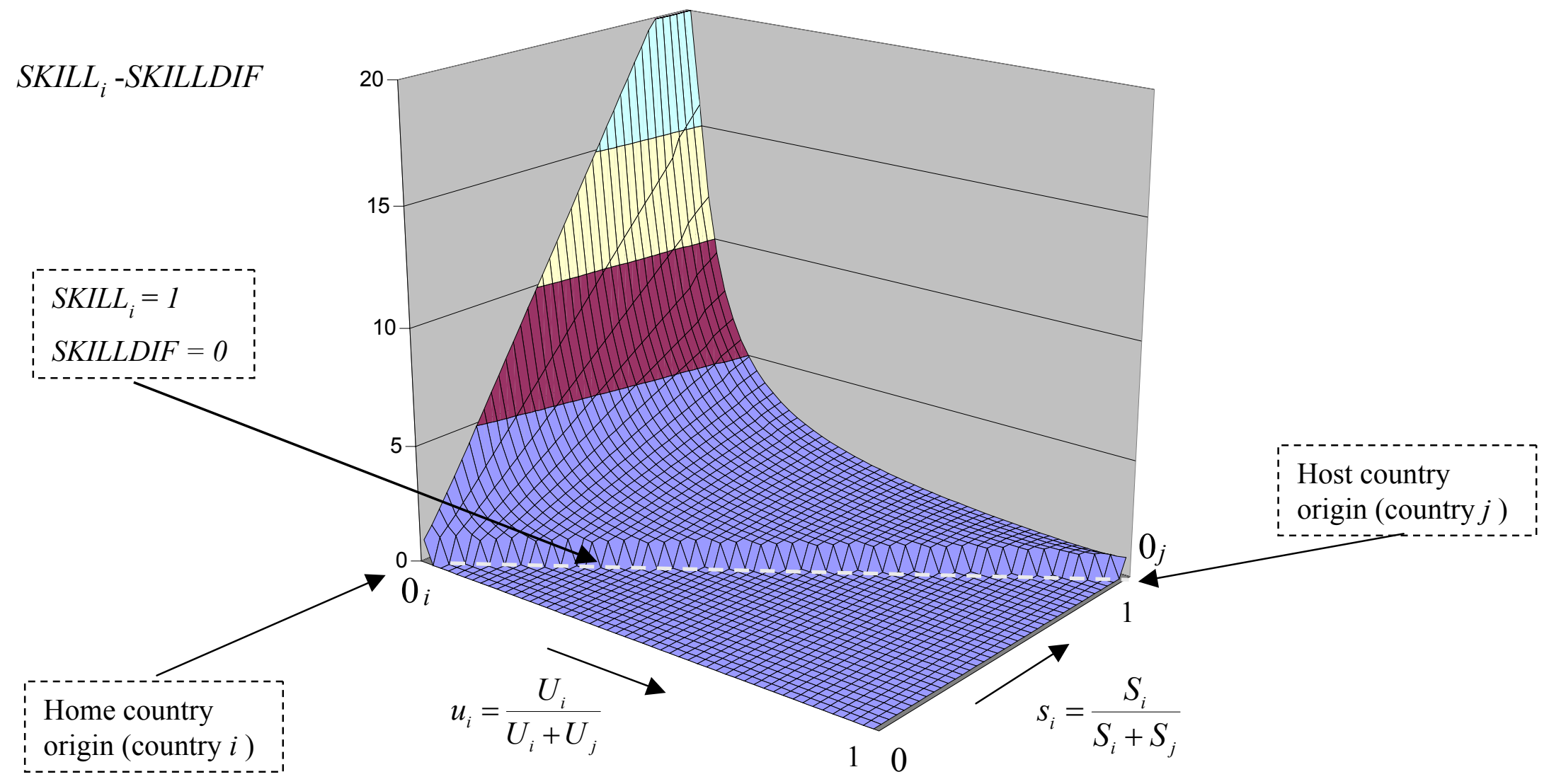

Figure 7: Illustrating the difference $S K I L L_{i}-S K I L L D I F$, when the home country is skilled labor abundant. 


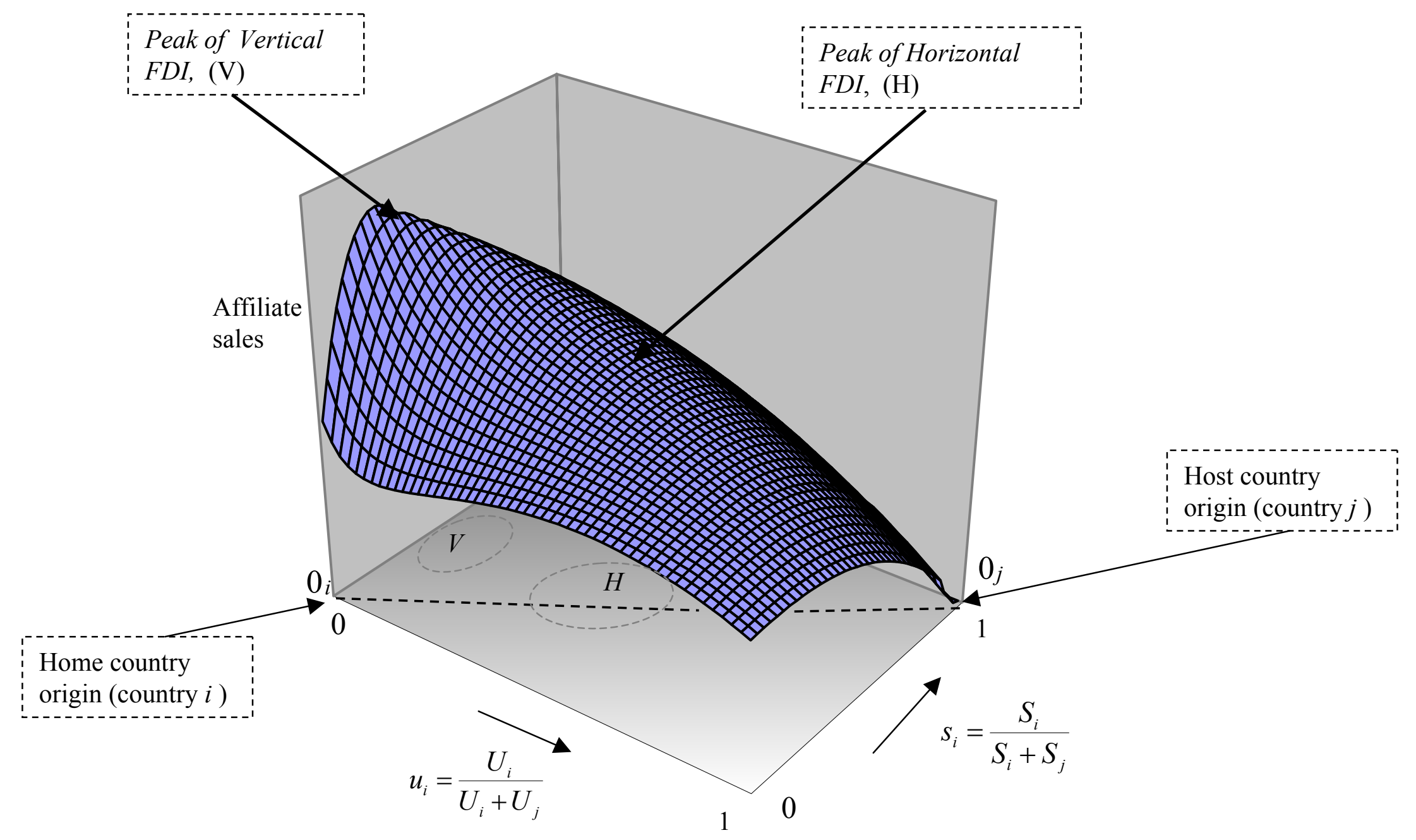

Figure 8: Illustrating predicted affiliate sales when using a polynom of degree three in $S K I L L_{i}$ in (1). 